REGE

29,2

102

Received 3 December 2020 Revised 15 September 2021 Accepted 7 October 2021

\section{Determining factors in the performance of integrated vocational education schools}

\author{
Marise Regina Barbosa Uemura and Graziella Maria Comini \\ Faculdade de Economia, Administração e Contabilidade, Universidade de São Paulo, \\ Sao Paulo, Brazil
}

\begin{abstract}
Purpose - The purpose of this paper is to identify the determining factors in the performance of integrated vocational education schools, in addition to management characteristics and specificities.

Design/methodology/approach - By means of a descriptive study with a qualitative approach, a case study was conducted in two schools located in the cities of Cotia and São Roque.

Findings - The following factors were identified: engagement and commitment of teachers; motivation and focus of teachers and students; team of professionals; commitment and focus of students; family involvement; leadership and climate and selection of students. The following characteristics were observed: participative leadership associated with the use of management tools; pedagogical leadership in partnership with the school community; monitoring of student performance; performance assessment and training of teachers related to career plan; selection of students and actions along the community.

Research limitations - The results reflect the vision of the schools' managers and teachers and not that of the managing institution. There is no intention whatsoever to obtain generalization to other ETECs but rather inferences that could shed light on future studies.

Practical implications - This research ratifies what has already been proven in the literature, showing that there are no isolated factors that interfere with performance, but an interrelationship among them, given the characteristics and peculiarities of each school.

Originality/value - This study is expected to contribute to guiding school managers and teachers in the search for quality education, whether vocational or regular basic education.
\end{abstract}

Keywords Technical and vocational education, School management, School administration, Public education Paper type Research paper

\section{Introduction}

Technical and vocational education has been the object of national and international studies, showing its importance in the economic and social context of several countries around the world, especially for the access of young people to the labor market. UNESCO considers technical and vocational education one of its priorities, alongside literacy and higher education, seeking to foster equitable, inclusive and quality education, as well as learning opportunities for all (Marope, Chakroune, \& Holmes, 2015).

Young people, especially from low-income classes, have less prospects for employment and income, so vocational education becomes a necessity, as highlighted by Ciavatta and Ramos (2011). Furthermore, when considering the integration of vocational education into high school, the value of this modality stands out, preparing young people who articulate science, culture and work, giving them the possibility to choose to pursue their studies in higher education or, if necessary, join the labor market (Frigotto, 2007).

(C) Marise Regina Barbosa Uemura and Graziella Maria Comini. Published in Revista de Gestão. Published by Emerald Publishing Limited. This article is published under the Creative Commons Attribution (CC BY 4.0) licence. Anyone may reproduce, distribute, translate and create derivative works of this article (for both commercial and non-commercial purposes), subject to full attribution to the original publication and authors. The full terms of this licence may be seen at http://creativecommons. org/licences/by/4.0/legalcode 
Although there is no system that assesses vocational education, students in the modality integrated to high school can take the National High School Examination - ENEM, in the Portuguese acronym, created in 1998, with the purpose of assessing the performance of students at the end of basic education (INEP, 2015b).

When looking at the average grades in ENEM 2014, the top performing mainstream public schools in the state of São Paulo, in addition to some federal schools, are the so-called ETECs (state technical schools), managed by the State Center for Technological Education Paula Souza, known as Centro Paula Souza (CPS), an entity associated to the Department of Economic Development, Science, Technology and Innovation (SDECTI). ETECs offer vocational education integrated to high school, in addition to regular high school, so their students also take ENEM exams.

In 2014, 46 ETECs were among the 60 best state schools across Brazil, considering the average grades of objective tests published by INEP (2015b). When considering the 2,000 first schools in Brazil, using the same criteria, 192 are public schools (federal, state or municipal administration), 65 located in the state of São Paulo. Out of these 65 public schools in the state of São Paulo, 54 are ETECs.

This situation gave rise to the motivation to better understand these schools, leading to the following question: what characteristics and specificities of management provide these schools with such results? To answer this research question, it will be necessary to identify the determining factors in the performance of vocational education schools integrated to high school, which characterizes the main objective of this study. As specific objectives, we seek to (1) identify the characteristics and specificities of management used in vocational education schools integrated to high school, which can be attributes for obtaining a better relative performance from their students; and (2) compare and analyze any differences and similarities among schools in different cities based on the surveyed factors.

To achieve these goals, we start from a theoretical framework that initially encompasses the contextualization of vocational education in Brazil, followed by assessment methods of this type of education, especially at high-school level, ending with school management and the factors pointed out by the literature that seek to explain how the school interferes with school performance.

\section{Theoretical framework}

\subsection{Vocational education}

Given its historical trajectory, technical and vocational education in Brazil is seen from different perspectives. From an assistance policy, marked by its origin in the 19th century, when it served the less favored population, as mentioned by Moura (2007), to other perspectives described by Manfredi (2002), as preparation to meet the needs of the production sector, and the idea of technological education for preparing workers, integrating preparation for work with high school. The author mentions vocational education, as a social right, as something to be incorporated into primary and secondary education projects, aimed at young people and adults. Ciavatta and Ramos (2011) point out vocational education as a need for young people, especially from the lower classes, who lack employment and income prospects.

Vocational education at high-school level is presented in Brazil in three ways: subsequent, which consists of high-school technical courses offered to those who have already completed high school; concomitant, for students who are attending high school, but with independent enrollments; and integrated, in which there is an integration of vocational education with high school (Moura, 2010). According to the author, in the latter, there is the "integration of work, science, technology, and culture, which are also integrated into a specific vocational education” (Moura, 2010, p. 883). Vocational education integrated to high school is seen positively, especially by the layers of the population that most depend on the public offer of 
REGE

29,2

104 this level of education, which can allegedly make it "easier to join the labor market" (Ciavatta \& Ramos, 2011, p. 35).

The network that offers vocational education at high-school level in the country is made up of educational institutions from the public sector (federal, state and municipal) and the private sector. This includes civil society organizations, non-governmental organizations (NGOs), workers unions, business unions (Manfredi, 2002), as well as organizations of the S system (Senai, Sesi, Senac, Sesc, Senar, Senat, Sest, Sebrae, Sescoop), considered by the author as "a parastatal Vocational Education network, organized and managed by trade union bodies representing businesses" (Manfredi, 2002, p. 179).

In Brazil, in 2014, there were 27,743 high school establishments, including those offering integrated vocational education, according to the 2014 School Census (INEP, 2015b). Out of these, 5,995 offer vocational education in one or more of the three modalities (integrated, concomitant or subsequent), $8 \%$ at the federal level, $33 \%$ at the state level, $2 \%$ at municipal level and $57 \%$ private.

The federal network has 482 establishments that offer vocational education at high-school level ( $8 \%$ of the total), including one or more modalities, accounting for $35 \%$ of enrollments in integrated vocational education. The state network, on the other hand, corresponds to $33 \%$ of the total educational establishments that offer vocational education, with 2,006 institutions in the country, accounting for $54 \%$ of enrollments in the modality integrated to high school.

Although less expressive, vocational education establishments in the integrated modality managed by the municipal government are also present in some regions of the country. In $2014,9 \%$ of the enrollments in this modality were in establishments managed by the municipal government, with $17 \%$ in the state of São Paulo, exceeding the participation of the federal network in this region, which was $5 \%$ (INEP, 2015c).

\subsection{Evaluation of vocational education at high school level}

Brazilian high school is assessed in two ways, the Basic Education Assessment System (SAEB) and the ENEM. The main purpose of SAEB is to evaluate basic education encompassing three external assessments, but only one involves secondary education: the National Basic Education Assessment - ANEB. It has proficiency grades in Portuguese and Mathematics, as part of the SAEB results made available by INEP, Institute of Educational Studies Anísio Teixeira, since 1995 (INEP, 2015d).

In 2007, INEP created the Brazilian Education Development Index, the IDEB, calculated from information on school approval obtained by the School Census (INEP, 2015a), and performance averages in the assessments carried out by SAEB and Prova Brasil. ENEM was created in 1998 to assess the performance of students graduating high school (INEP, 2015b). Despite having its effectiveness questioned by some specialists, the ENEM ranking, published annually since 2004, is the only performance indicator with national coverage that makes it possible to at least assess the quality of basic education offered by secondary schools (Andrade \& Soida, 2015). As there is no national system for assessing vocational education at the high-school level, schools that offer the integrated modality are assessed based on the participation of their students in ENEM, therefore, by the content related to high school itself and not to the technical course.

\subsection{School management and performance-related factors}

National and international studies present factors that contribute to the good performance of basic education schools. As Brooke and Soares (2008) point out in their collection of research studies on school effectiveness, after educational studies carried out in 1960 [1], concluded that school did not make much difference (but the social background of students), new studies began to investigate the factors associated with academic success. 
Sammons, Hillman, and Mortimore (1995) presented 11 key factors for effective schools, identified from a literature review of studies on school effectiveness conducted in several countries. The authors emphasize that the factors may contribute to a better understanding of the effectiveness mechanisms, but they should not be considered independent of each other. They are: (1) professional leadership, (2) shared goals and visions, (3) learning environment, (4) concentration on teaching and learning, (5) clear teaching and objectives, (6) high expectations, (7) positive incentive, (8) progress monitoring, (9) student rights and responsibilities, (10) home-school partnership and (11) learning-oriented organization. Although they emphasize that they are interrelated, professional leadership is highlighted as a factor that strongly impacts others and appears in almost all studies analyzed, corresponding not only to the quality of leaders, but to the role they play, management style and the relationship with school vision, values and goals (Sammons et al., 1995).

These 11 factors served as reference for further studies, with adaptations according to the studied context or research objectives (Lima, 2012). In countries in the Ibero-American region, for example, studies bring factors such as school and classroom atmosphere, leadership, shared goals, high expectations, methodology or teamwork of teachers that contribute to optimizing quality and equity levels in schools (Murillo, 2003). The author reinforces that, in addition to having factors in common with the review by Sammons et al. (1995), new elements were also found and appear in virtually all the studies analyzed, such as economic and material resources, in addition to factors related to student performance, directly associated with the quality of education. Factors related to teachers also frequently appear, especially those related to education background, stability and working conditions.

In Brazil, the implementation of SAEB in 1995 made it possible to analyze both the capacity of the education system and students' learning (Brooke \& Soares, 2008). School effectiveness factors related to school organization and management were addressed in 16 papers, between 2001 and 2018, according to a literature review conducted by Passone (2019), with the following dimensions being identified: planning, democratic management, administrative management, pedagogical management, shared goals, family and local community participation, organizational climate and leadership.

To properly focus on the factors that guided this research, a brief description of the aspects of school management and some of its results are given below.

2.3.1 Leadership/management. Leadership is considered a key factor in studies on school effectiveness, both in primary and secondary schools (Sammons, 2008; Sammons et al., 1995). According to Soares (2002), schools with an organized administrative structure, active and participative leadership, have shown better results in the proficiency scale used by the government of the state of Minas Gerais. The leadership that is involved with school issues and encourages the participation of other professionals is able to reverse adverse situations more easily, in addition to putting into practice pedagogical projects that improve student performance.

Paro (2012, p. 69) highlights the contribution of school administration in taking care of the "best possible use of both objective and subjective resources, through the coordination of collective human effort and the rationalization of work." School management had a direct impact on the performance in mathematics of ninth-grade students in the Prova Brasil, and it was also found that the higher the level of complexity in school management, the more impactful school management will be on performance (Gobbi, Lacruz, Américo, \& Zanquetto Filho, 2020).

2.3.2 Internal climate. This aspect involves both the academic and disciplinary climate of the school, teachers' interest in student performance, respect and discipline in the classroom (Alves \& Franco, 2008; Andrade \& Laros, 2007; Soares, 2002), as well as the organizational climate associated with a good relationship between the pedagogical team and other school professionals (Miranda, 2012; Passone, 2019). The internal climate favors interpersonal 
REGE

29,2

106

relationships, in addition to facilitating the implementation of pedagogical proposals (Soares, 2002). Student performance can be positively impacted by factors such as leadership and school climate, as found by Oliveira and Souza Waldhelm (2016) in their research with data from municipal and state schools in Rio de Janeiro (Alves \& Franco, 2008).

2.3.3 Teachers. The academic degree and career level of teachers, in addition to salaries, were identified as one of the aspects that impact the performance of schools in a study conducted by Alves and Passador (2011) in the state of Goiás. The importance of the academic degree and qualification of teachers, teachers who are committed to learning and who have high expectations regarding performance, are considered factors associated with school performance (Andrade \& Laros, 2007; Miranda, 2012; Santos Filho, 2015; Soares, 2002).

2.3.4 Infrastructure. In addition to aspects related to physical, financial and pedagogical resources, this study also covers other factors external to the school, such as staff hiring and control over the type of student admitted (Soares, 2002). The author observes that factors related to the infrastructure of Brazilian schools directly affect school performance; however, the scarcity of resources does not, in isolation, justify poor performance. Alves and Passador (2011) found that students of high socioeconomic status from schools with incomplete infrastructure do not always perform well in educational assessments, indicating that there are other factors involved in this performance.

2.3.5 Pedagogical management/teaching characteristics. Like administrative management, pedagogical management is also considered a relevant factor for school performance (Sammons, 2008; Sammons et al., 1995), including the mobilization of supervisors and teachers to achieve educational goals (Soares, 2002), the existence of a pedagogical project and its adequacy to the school's needs (Brooke \& Soares, 2008). The pedagogical processes developed by teachers are related to their higher education (Santos Filho, 2015). Close pedagogical monitoring of students and teachers was one of the characteristics identified by Faria and Alves (2021) as contributing to the good performance of one of the schools analyzed in their study.

2.3.6 Relationship with families/community. The partnership of the family with the school and the effective monitoring by parents over the children's learning process is one of the key factors for effective schools (Sammons, 2008; Sammons et al., 1995). Issues such as the involvement of parents in the school administration and the involvement of the school in the community are also considered here (Soares, 2002). Studies that address family and local community participation in the school consider the contribution of these actors for a democratic and participative management to be relevant (Passone, 2019). Improvements in the students' learning process and the reduction of absences can be achieved by bringing the principals and faculty closer to parents and guardians (Silva, Silva, \& Lima, 2020).

2.3.7 Management practices. This dimension is related to leadership and encompasses practices such as evaluating and monitoring school performance, setting goals, shared vision and goals (Luck, 2009; Oliveira \& Souza Waldhelm, 2016; Sammons et al., 1995). Schools that have shared objectives and goals between school management and the school community show greater commitment from the team and, consequently, better results in the performance of their students (Lima, 2012).

Based on the theoretical framework exposed here, the aspects of school management that guided the data collection of this study are: leadership/management, internal climate, teachers, infrastructure, pedagogical management/teaching characteristics, relationship with families/community, and management practices, which will be illustrated in the next section.

\section{Methodological procedures}

\subsection{Type of research}

A descriptive study with a qualitative approach was conducted, which involves obtaining descriptive data through direct contact with the studied situation, and seeks to understand 
the phenomena from the perspectives of the participants (Godoy, 1995). The modality chosen was case study, one of the most used types of qualitative research, which consists of "an empirical investigation that researches phenomena within their real context [...] where the researcher has no control over events and variables, seeking to learn the totality of a situation [... ] and understand and interpret the complexity of a concrete case" (Martins \& Theóphilo, 2009, p. 61).
Integrated vocational education schools

\subsection{The cases}

For the purposes of this research, we sought to identify two schools in municipalities with up to 250,000 inhabitants, preferably in the region of Greater São Paulo (GSP). Initially, we obtained a ranking from the 185 ETECs that participated in ENEM 2014, ordering from the highest to the lowest average score of the objective tests. The first school to be chosen was the ETEC from Cotia, a city located in the western region of GSP, which, in 2010, had 201,150 inhabitants (IBGE, 2016). The school occupies $34^{\text {th }}$ place among all ETECs, according to ENEM 2014, and 1,617 ${ }^{\text {th }}$ place in the general ranking in Brazil. The search for the second school involved two criteria: that it was also well positioned in the ranking of ETECs of the selected group and that it was close to Cotia. Of the cities close to Cotia that are part of the GSP, only Embu and Osasco have ETECs. The units in Osasco are not among the top 40 ETECs, and the one in the city of Embu is a few positions below the school in Cotia. In an expanded survey, without considering only ETECs in GSP, we decided to include the ETEC from São Roque, a city neighboring Cotia, but considered to be part of the state, micro-region of Sorocaba. This school is ranked ninth among all ETECs and is the 944th in the general ranking of schools throughout Brazil.

\subsection{Sources of evidence}

Documentary research, interviews and direct observation were used. The documentary research included the analysis of documents provided by the schools themselves, such as their respective multiannual management plan (PPG), copies of the teaching work plan (PTD), in addition to the structure of the registration and assessment systems used.

For the interviews, three different scripts were created based on the factors identified in the national and international literature, including general and some specific questions related to the positions held by each respondent (director, pedagogical coordinator/ educational advisor and teacher). In April and May 2016, nine interviews were conducted, totaling $12 \mathrm{~h}$ and $15 \mathrm{~min}$ of recording.

The third source of evidence was the direct observation in the studied environment, which allows the collection of situational data and also involves the observer's sensory perception (Martins \& Theóphilo, 2009). The events observed were: (1) lecture on the quality of schools, given to students by the philosophy teacher during the Paulo Freire Week (ETEC Cotia); (2) mathematics class stops at the second year of integrated technical education (ETEC São Roque); (3) observations in the teachers' lounge in both schools; and (4) class council meeting held in the first week of July (one at each school).

\subsection{Method for analyzing the results}

Data analysis, defined by Yin (2010, p. 136) as the step that "[. . . consists of examining, categorizing, tabulating, testing or otherwise recombining both quantitative and qualitative evidence to address the initial propositions of a study," was based on the aspects of school management identified in the literature review. Yin (2010) suggests, as one of the analytical strategies to follow the theoretical propositions of the research, to analyze data. Thus, based on the aspects of school management that guided the preparation of the interview scripts, we 
REGE

29,2

\section{8}

described the different items that make up each theme and the authors referred to in the theoretical framework, giving rise to Table 1, which shows the seven categories and aspects that guided data encoding.

Each item guided the coding of the interviews' answers and the documents collected, made using the NVivo software (http://www.qsrinternational.com/nvivo-portuguese). According to Yin (2010), computer-assisted qualitative data analysis software (CAQDAS) has been increasingly used and helps researchers to code and categorize large amounts of narrative texts, collected from open interviews or from historical documents.

\section{Analysis of results 4.1 Description of cases}

The state technical school of Cotia started in July, 2009, as a decentralized class of the ETEC de São Roque. The model consists of agreements between the CPS and the state regular education system or with municipal governments to offer technical courses in cities that do not yet have an ETEC. In December 2009, ETEC Cotia effectively opened, and in 2010, it

\begin{tabular}{|c|c|c|}
\hline \multicolumn{2}{|c|}{ Aspects of school management - basis for data encoding } & \multirow{2}{*}{$\begin{array}{l}\text { Authors } \\
\text { Andrade and Laros (2007), Gobbi et al. } \\
\text { (2020), Murillo (2008), Paro (2012), } \\
\text { Sammons (2008), Sammons et al. } \\
\text { (1995), Soares (2002) }\end{array}$} \\
\hline $\begin{array}{l}\text { Leadership/ } \\
\text { management }\end{array}$ & $\begin{array}{l}\text { Administrative and pedagogical } \\
\text { leadership, collaborative work of the } \\
\text { management team, participative } \\
\text { approach }\end{array}$ & \\
\hline Internal climate & $\begin{array}{l}\text { Existence of a climate of order, } \\
\text { expectation regarding the future } \\
\text { performance of students }\end{array}$ & $\begin{array}{l}\text { Alves and Franco (2008), Miranda } \\
\text { (2012), Murillo (2003), Oliveira and } \\
\text { Souza Waldhelm (2016), Passone } \\
\text { (2019), Soares (2002) }\end{array}$ \\
\hline Teachers & $\begin{array}{l}\text { Adequate academic background and } \\
\text { professional experience, training } \\
\text { opportunities, satisfaction with work and } \\
\text { salary, interpersonal relationships }\end{array}$ & $\begin{array}{l}\text { Alves and Passador (2011), Andrade } \\
\text { and Laros (2007), Miranda (2012), } \\
\text { Murillo (2003), Santos Filho (2015), } \\
\text { Soares (2002) }\end{array}$ \\
\hline
\end{tabular}

Infrastructure between teachers, teacher support, academic background/salary/career plan Lack of financial/pedagogical resources; infrastructure and external factors; school control over teacher selection and dismissal and type of students admitted; library, laboratories, sports court management/teaching characteristics

Relationship with families/community

Table 1. Aspects of school management obtained from the theoretical framework

Management practices
Pedagogical

Academic climate, teacher-student relationship, pedagogical practices, teaching methodology, pedagogical project, concentration on teaching and learning, monitoring student progress and performance

How the school encourages parental involvement, involvement of the school in the community, involvement of parents in school administration, home-school partnership shared goals and visions

Andrade and Laros (2007), Medeiros, Alves, Passador, and Passador (2011), Murillo (2008), Soares (2002)

Andrade and Laros (2007), Faria and Alves (2021), Murillo (2003), Paro (2012), Sammons (2008), Sammons et al. (1995), Santos Filho (2015), Soares (2002)

Passone (2019), Sammons (2008), Sammons et al. (1995), Silva et al. (2020), Soares (2002)

Lima (2012), Luck (2009), Murillo (2008), Oliveira and Souza Waldhelm (2016), Sammons (2008), Sammons et al. (1995)

Source(s): Prepared by the author 
started offering technical courses, as well as high school. Technical education integrated to high school (ETIM) has been offered since 2013. Regular high school was discontinued in 2017, and only ETIM remained, according to CPS. In 2016, the school had 580 students, 120 of which were in high school and 108 in ETIM, the others were students from technical courses (concomitant and subsequent modalities).

Among students in ETIM classes, $68 \%$ come from public schools, while in regular highschool classes, this percentage is a little lower, 55\%. As for family income, in ETIM, $61 \%$ of students have a family income ranging from one to three minimum wages, while in regular high school, this percentage drops to $38 \%$.

ETEC São Roque began as a decentralized class of two ETECs in the city of Sorocaba, starting to have its own management in November 2002. Regular high school is no longer offered since 2015, with only one class graduating in 2016. In total, the school had 479 students, 80 in integrated education and 40 in regular high school.

Similar to what was observed at ETEC Cotia, the students in ETIM classes at ETEC São Roque mostly came from public institutions as well. Considering the two classes, the first year of ETIM in computer classes and the second year of ETIM in logistics, $68 \%$ are from public schools. This percentage reaches $77.5 \%$ when considering separately the second year of ETIM in Logistics.

As for family income, there was no significant difference between the two courses (ETIM and regular high school), with $58 \%$ of ETIM students with family income ranging from one to three minimum wages and $57 \%$ of high-school students in this same range.

\subsection{Management of Centro Paula Souza}

A São Paulo State government agency associated with SDECTI, CPS is responsible for managing 223 state technical schools (ETECs) and 73 technology colleges (FATECs). ETECs are present in 336 cities and serve 212,000 students in technical education, high school and technical education integrated to high school (CPS, 2020). They offer the modalities of ETIM, high school and technical education, totaling 185 technical courses for the industrial, agricultural and service sectors, including blended, online and youth and adult education (EJA) modalities.

The institution adopts methodologies for monitoring the quality of its units. There are two systems, one is the school observatory, consisting of blocks that involve school practices and cover the different sectors and departments of the school, implemented in 1998 by the technical education coordination - CETEC (CPS, 2020). The other is the institutional assessment system (SAI) called WebSAI, a research platform that addresses three segments: inputs, process and result, generating indicators related to ETECs (CPS, 2020). The process involves the participation of teachers, employees, directors, students, former students and parents, and its results guide decisions in teaching and administrative aspects, allowing the management team and teachers to identify opportunities for improvement and set goals.

\subsection{Management characteristics and specificities}

This section discusses the characteristics and specificities identified in both schools, which can be considered as attributes for achieving good performance, starting from the aspects defined for this investigation (Section 3.4).

The participative and democratic management proved to be one of the main characteristics of the directors of both schools. With the profile of a manager, as the interviewed professors state, the director of ETEC Cotia plays his role of analyzing indicators, complying with norms and rules, and demanding records in the management systems. However, he shares decisions with coordinators and teachers, including showing the results of actions taken together. Listening to teachers' expectations is one of the points highlighted by him: "We have a 
REGE 29,2 meeting at the beginning of the year, we have breakfast, talk, it is really cool. We listen to the teacher's expectations, ask what they expect for this year, this is very valid."

The director of ETEC São Roque is in her second term. Despite having no degree in management (she has a degree in nursing), her profile, which is more related to humanities, is highly valued at the school by her team. One of the teachers points out "The director is very welcoming, humane, professional, and knows how to recognize a good job; she motivates us a lot."

Although the coordination is responsible for the direct management of the teachers, the management style of the direction reflects on the way these professionals are managed. This can be seen in the testimony of the pedagogical coordinator of ETEC São Roque: "The relationship is good, the same atmosphere that the [director] creates, of a participative management, we also try to create. The same way the [director] does with us, we do with the teachers, we ask them, nothing is imposed."

Even with different profiles, both directors exert influence on the team of coordinators, which in turn reflect on the teachers, which corroborates previous studies. Active and participative leadership contributes to the good results of schools (Soares, 2002), and the way leaders play their role, their management style and their relationship with the school's objectives is important (Sammons et al., 1995).

In Cotia, the management focus on monitoring indicators, measuring results and meeting targets makes the school achieve good student performance. In São Roque, a director that is more "humane", "welcoming" and closer to teachers and coordinators, thus ensuring a good atmosphere between teachers and coordinators, also contributes to achieving good results. Characteristics such as the organizational climate, associated with good interpersonal relationships, can positively impact student performance (Miranda, 2012; Oliveira \& Souza Waldhelm, 2016; Passone, 2019; Soares, 2002).

The pedagogical structure of the schools enables a partnership between pedagogical and course coordinators and educational advisors, who seek, along with teachers, students and families, to improve the teaching-learning process. This reality is consistent with what Paro (2012) states: according to him, the learning process should be seen as a priority by the entire coordination. In addition, Soares (2002) reinforces that the leadership that is involved with school issues is able to reverse adverse situations more easily, in addition to putting into practice pedagogical projects that improve student performance. The pedagogical coordinator of ETEC São Roque exemplified this possibility of reversal: "[...] we had a [student] who was very complicated, but he evolved. But at municipal schools, only students who are good continue, [...] there is no follow-up like calling the parents."

Among the aspects that encompass the teaching characteristics, some stand out. The fulfillment of the pedagogical project of the integrated course is followed by the course and pedagogical coordinators. Even the students themselves contest the fulfillment of the content, if they deem it necessary. The existence of a pedagogical project and its proper monitoring also contributes to school effectiveness (Murillo, 2003; Soares, 2002). Another aspect is the monitoring of student performance, carried out by both schools with the aid of their own system (NSA - new academic system), which records the history of student performance and allows course and pedagogical coordinators to monitor the learning process. When the need to talk to the student or parents is identified, the educational advisor is involved. In both schools, based on the observed meetings, it can be seen that the majority knows each student and their characteristics, including those whose parents have already been called to participate more actively - or not - in their children's school life. Monitoring student progress and home-schoolpartnership are among the key factors for good performance (Faria \& Alves, 2021; Sammons et al., 1995; Silva et al., 2020).

As for the teachers, some aspects are highlighted. Their performance assessment is made up of internal systems (institutional, SAI and school observatory), in addition to the scoring 
system. The pedagogical coordinator of ETEC São Roque highlights: "[ . . ] here everything is linked to the teacher's score, there has been a significant improvement. For example, this year I only had one case of a teacher who submitted [documents and records in the system] after the deadline. The attendance at the pedagogical meetings is also considered." This is a people management tool that certainly contributes to the performance of the teaching team.

The search for professional improvement and qualification is encouraged by CPS, being related to the career plan. The system that feeds the "steps" of the career plan involves from day-to-day factors, such as attendance and commitment, in addition to encouraging the improvement of their skills, with points for qualification courses, specializations and even master's and $\mathrm{PhD}$ courses. The academic degree and career level of teachers are aspects that impact the good performance of schools (Alves \& Passador, 2011); however, compensation, a factor also found by the authors as significant, is not favorable in the case of the studied ETECs. According to one of the interviewed teachers, "the salary is not so good, teachers need to teach in several places, they cannot pay enough attention [...]."

In terms of infrastructure, even with some difficulties and limitations, both schools demonstrated that they manage the existing resources, adapting to the reality of space and financial resources restrictions. The reality of public schools, with restrictions and limitations, is evident; however, the management proves that it is possible to do the least and sometimes even more than expected with the available resources.

Considered a specificity of ETECs, student selection is necessary, since demand is greater than the offer of vacancies. Candidates take a classification test (admission exam) consisting of 50 questions related to different areas of knowledge, covering the content of elementary school II (sixth to ninth grade). Candidates from public schools and Afro-descendants receive an additional score. Even selecting students with better performance, in both schools, teachers and coordinators face difficulties with the inadequate background of admitted students. One of the interviewed teachers of ETEC Cotia says "The admission exam levels students, it has all subjects, but even so they get here with significant school lag."

\subsection{Determining factors in school performance}

To fulfill the main objective of this study, which is to identify the determining factors in the performance of vocational education schools integrated to high school, an open question was made to all respondents, directors, coordinators, educational advisors and teachers: "To what do you attribute the performance of students from this school in ENEM?" The respondents designated one or more combined factors, emphasizing the one they believed to be the most important. The analysis of the answers resulted in the formation of six groups of factors in the following order:

(1) Engagement and commitment of teachers;

(2) Motivation of teachers and students and focus on achieving goals;

(3) Professional team, including pedagogical and course coordinators, and educational advisors;

(4) Commitment and focus of students;

(5) Family involvement;

(6) Leadership and climate; and

(7) Selection of students.

It is worth noting that the first three were pointed out with greater emphasis by the respondents, which is expected according to Sammons (2008), when stating that one factor
Integrated vocational education schools 
REGE

29,2

112

may impact more than another. In addition, the interrelationship among them, also evidenced by the author, can be seen in the speech of the pedagogical advisor of ETEC Cotia, by highlighting the engagement of teachers and, at the same time, the participation of students: "One thing leads to the other, it is even due to the excessive engagement of teachers, which puts us in a privileged position, so much so that our goal was, in 5 years, to place ourselves among the top 50 in ENEM." In addition to the teachers, the success attributed to the entire team of professionals is reinforced by the teacher of ETEC São Roque: "We are highly focused on it. Students also want to pass ENEM, they want to go to university. Their part together with ours is what really makes the difference." The relationship is also made with the leadership style, which favors autonomy and teamwork, providing a favorable internal climate. The director of ETEC São Roque says, "We have it here, the atmosphere is different, there is no competition, it's not a competitive environment, there's a partnership."

Family involvement was also mentioned as one of the determining factors. The educational advisor of ETEC São Roque values individualized treatment and family involvement with the school: "I think that first there is a closer involvement of the family with the school, we already know the student individually, we really care about it, the focus is on quality, on good development."

Even though the selection of students was mentioned as one of the factors, based on the data collected, it was possible to verify that schools face the challenge of admitting students with school lag. Thus, this is another factor that cannot be considered in isolation when it comes to determining performance.

Even though they are not among the factors mentioned in the literature on school management, the motivation of teachers and students and the focus, especially on teachers, were mentioned by the respondents from the surveyed schools as factors that contribute to the good performance of students (Figure 1). Despite being related to higher education, motivation was addressed by Guimarães and Lima (2016) in their study on educational entrepreneurship, emphasizing overcoming difficulties and the desire to "make it happen" as determining factors for teachers. The set of reasons that act on the individual (Michaelis, 2015) seems to act on students and school staff to achieve the goals. It is not possible to generalize the results of this research to all other schools in the CPS network that offer integrated education; however, it can be stated by the results obtained that the fact of being seen as good public schools already makes the student joining the ETECs surveyed adapt their behavior, their motivation. And, on the other side, the teachers and all the staff involved, seek to do a good job.

Although the factor "teachers' engagement" predominated in ETEC Cotia and the factors "motivation and focus" and "team" predominated in São Roque, the importance of these three aspects, as well as the other four mentioned, is notorious. On the one hand, a predominantly democratic and participative management that reflects from the director to the coordinators and, from these to the teachers. The search for meeting goals, improving indicators and achieving good results stems from teamwork, which affects the direction, teachers, coordinators and, also, other administrative employees. And, on the front line, the teachers, who despite facing the difficulties inherent to teaching, find motivated students and manage to do a good job with the support of the school's pedagogical and administrative staff.

\section{Final considerations}

The main purpose of this study was to identify the determining factors in the performance of vocational education schools integrated to high school. For this, two state technical schools under the management of CPS were selected. In addition, we sought to identify management characteristics and specificities of these schools, analyzing similarities and differences. 


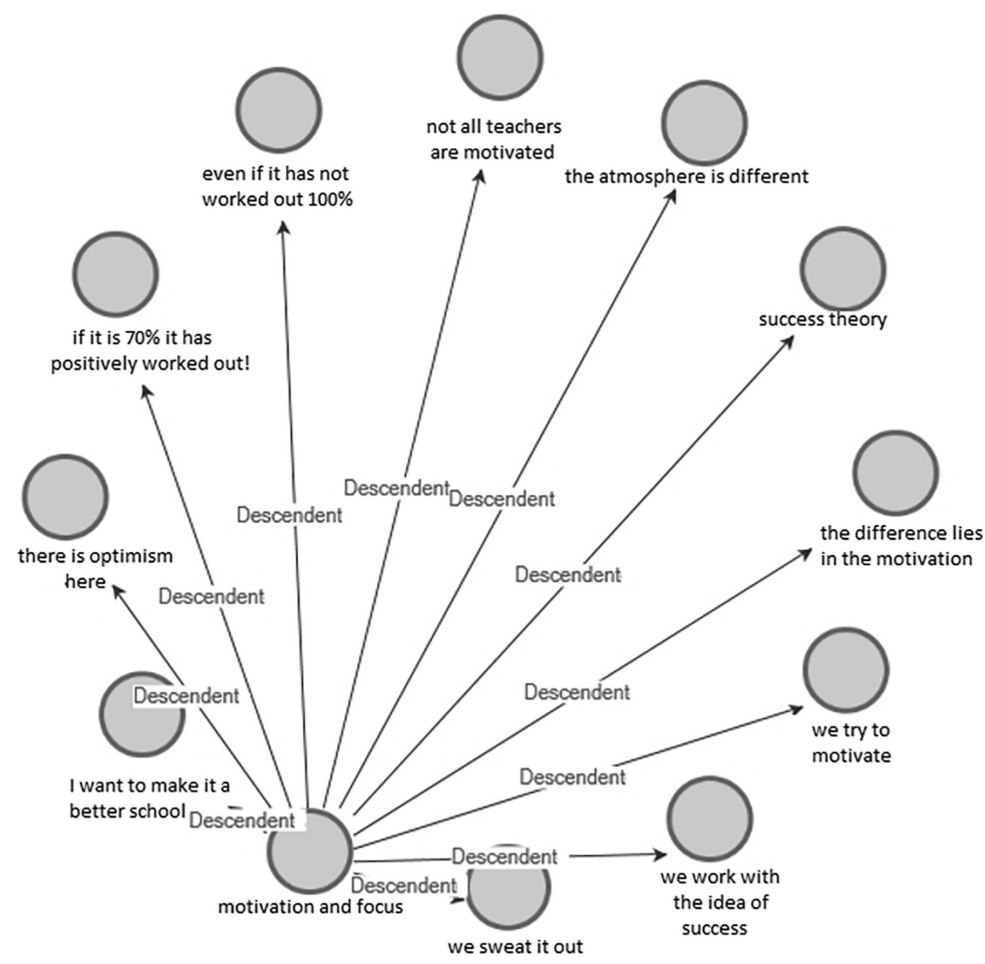

Source(s): Figure generated from the author's analysis using the NVivo software
Integrated vocational education schools

113

In view of the expansion of the network of ETECs, especially in the 2000s, regular high school that was previously offered was gradually replaced by technical education integrated to high school, as is already the case of the surveyed ETECs [2]. Therefore, the science, culture and work dimensions were combined, corroborating what Ramos (2008, p. 10) proposed in his analysis regarding the conception of integrated education: "[...] adding to the minimum required for high school, a workload intended for specific qualification for the exercise of technical professions, or for scientific initiation, or for the expansion of the cultural background."

The admission into higher education is one of the main objectives of students who attend integrated education in the surveyed schools, according to the respondents. Although this may seem to distort the role of vocational education at high school, whose primary function is to provide technical background to join the labor market, this does not limit its value. Even if they start higher education before joining the labor market, the experience of having had additional technical education during high school becomes an advantage in the personal and professional aspect.

Despite some deficiencies pointed out with regard to the schools' infrastructure, it is clear that both ETECs have the minimum resources for their proper operation. As a result, the schools are able to focus their efforts on improving administrative and pedagogical management, unlike many public schools that have not yet reached this level of infrastructure.

It is also worth noting that the socioeconomic profile of students must also be considered. As noted by Alves and Passador (2011), there is a relationship between performance in 
REGE

29,2

assessments and the socioeconomic background of students. In Cotia, $65 \%$ of the students in the integrated technical education classes are in the range of three or more minimum wages of family income, and in São Roque, $73 \%$.

As evidenced by the existing literature, this research also showed that there are no isolated factors that interfere with performance, but an interrelationship among those that predominate, given the characteristics and peculiarities of each school. There is no successful school without interested students, there is no quality school without a motivated and focused teacher, there is no school with good performance without a management team committed to achieving good results. Each party involved is required to do their best, including responsible public institutions, aiming at the true transformation that quality education brings to a society.

This study is expected to contribute to guiding school managers and teachers, and even students and their families, in the search for quality education, whether vocational or regular basic. In addition, it also aims to provide the opportunity for CPS to make comparisons with other schools in its chain.

The results reflect the vision of the schools' managers and teachers and not that of the managing institution, i.e. CPS. Moreover, there is no intention whatsoever to obtain generalization to other ETECs in the state of São Paulo, but rather inferences that could shed light on future studies.

The use of criteria from ENEM to assess integrated vocational education can also be considered a limitation of the study, as this indicator does not assess the student in terms of the content of technical subjects. However, this was the only indicator available that allowed the identification of ETECs with better performance in relation to others.

The choice of two ETECs with significant performance in ENEM allowed us to compare and analyze the effect of management on their performance. However, for future studies, we suggest the analysis of schools with different performances, enabling a comparison of the management characteristics of each one.

Since not all actors involved in the school were interviewed, such as students and their families, future research may include them in the process, expanding the scope of the investigation.

\section{Notes}

1. Survey conducted by James S. Coleman and his colleagues in the 1960s, known as the "Coleman Report" (Brooke \& Soares, 2008).

2. In $2016,76 \%$ of basic education vacancies (high school and integrated education) were in the integrated education modality (CPS, 2016).

\section{References}

Alves, M. T. G., \& Franco, C. (2008). A pesquisa em eficácia escolar no Brasil: evidências sobre o efeito das escolas e fatores associados à eficácia escolar. In Pesquisa em eficácia escolar: origem e trajetórias (pp. 482-500). Belo Horizonte: UFMG.

Alves, T., \& Passador, C. S. (2011). Educação Pública no Brasil: condições de oferta, nível socioeconomico dos alunos e avaliação (1a edição). São Paulo -SP: Annablume.

Andrade, J., \& Laros, J. (2007). Fatores Associados ao Desempenho Escolar: Estudo Multinível com Dados do SAEB/2001. Psicologia: Teoria e Pesquisa, 23(1), 33-42.

Andrade, E., \& Soida, I. (2015). A qualidade do ranking das escolas de ensino médio baseado no ENEM é questionável. Estudos Econômicos, 45(2), 253-286.

Brooke, N., \& Soares, J. F. (2008). Pesquisa em eficácia escolar: origem e trajetórias. (UFMG, Ed.), Belo Horizonte: Editora UFMG. 
Ciavatta, M., \& Ramos, M. (2011). Ensino Médio e Educação Profissional no Brasil: dualidade e fragmentação. Revista Retratos Da Escola, 5(8), 27-41.

CPS (2016). Cetec CPS-Centro Paula Souza. Available from: http://www.cpscetec.com.br/bdcetec/index.php.

CPS (2020). Centro Paula Souza. Available from: https://www.cps.sp.gov.br/.

Faria, P. S. D. P., \& Alves, M. T. G. (2021). Índice De Desenvolvimento Da Educação Básica E Eficácia Escolar: Evidências De Uma Pesquisa Comparativa. Revista de Gestão e Avaliação Educacional, 9(18), 1-20.

Frigotto, G. (2007). A Relação da Educação Profissional e Tecnológica com a Universalização da Educação Básica. Educação \& Sociedade Campinas, 28(100), 1129-1152.

Gobbi, B. C., Lacruz, A. J., Américo, B. L., \& Zanquetto Filho, H. (2020). Uma boa gestão melhora o desempenho da escola, mas o que sabemos acerca do efeito da complexidade da gestão nessa relação?. Ensaio: Avaliação e Politicas Públicas Em Educação, 28(106), 198-220.

Godoy, A. S. (1995). Introdução à pesquisa qualitativa e suas possibilidades. Revista de Administração de Empresas, 35(pesquisa qualitativa), 57-63.

Guimarães, J. D. C., \& Lima, M. A. M. (2016). Empreendedorismo educacional: reflexões para um ensino docente diferenciado. Revista Pensamento Contemporâneo Em Administração, 10(2), 34.

IBGE (2016). IBGE Cidades. Available at: http://cidades.ibge.gov.br/xtras/perfil.php? lang $=\&$ codmun $=351300 \&$ search $=\% 7 \mathrm{C} \% 7$ Cinfogr $\%$ E1ficos:-informa $\%$ E7 $\%$ F5es-completas (accessed 2 June 2016).

INEP (2015a). Índice de Desenvolvimento da Educação Básica - Ideb. Available at: http://download. inep.gov.br/educacao_basica/portal_ideb/o_que_e_o_ideb/Nota_Tecnica_n1_concepcaoI DEB.pdf.

INEP (2015b). Instituto Nacional de Estudos e Pesquisas Educacionais Anísio Teixeira. Available at: $\mathrm{http} / /$ portal.inep.gov.br/web/enem/sobre-o-enem.

INEP (2015c). Instituto Nacional de Estudos e Pesquisas Educacionais Anísio Teixeira. Available at: http://portal.inep.gov.br/microdados (accessed 5 June 2016).

INEP (2015d). Instituto Nacional de Estudos e Pesquisas Educacionais Anísio Teixeira - SAEB. Available at: http://portal.inep.gov.br/educacao-basica/saeb (accessed 11 September 2015).

Lima, A. M. G. (2012). Fatores Associados à Eficácia Escolar: Estudo de Instituições Educacionais Públicas Municipais de Fortaleza - CE. Universidade Federal do Ceará.

Luck, H. (2009). Dimensões da gestão escolar e suas competências. Curitiba: Editora Positivo.

Manfredi, S. M. (2002). Educação Profissional no Brasil. São Paulo -SP: Cortez.

Marope, P. T. M., Chakroune, B., \& Holmes, K. P. (2015). Liberar o potencial: transformar a educação e a formação técnica e profissional. In Organização das Nações Unidas para a Educação, Ciência e a Cultura. Brasília: UNESCO.

Martins, G. D. A., \& Theóphilo, C. R. (2009). Metodologia da investigação científica para ciências sociais aplicadas. São Paulo: Atlas.

Medeiros, M. D. L., Alves, T., Passador, J. L., \& Passador, C. S. (2011). Administração e políticas públicas em educação: uma revisão sistemática da produção do EnANPAD e EnAPG de 1997 a 2009. Revista de Ciências Da Administração, 13(30), 61-87.

Michaelis (2015). Dicionário Brasileiro da Lingua Portuguesa. São Paulo: Melhoramentos.

Miranda, J. A. D. A. (2012). Fatores de eficácia associados à gestão escolar e sua relação com os resultados de desempenho da escola. Universidade Federal de Juiz de Fora.

Moura, D. H. (2007). Educação Básica e Educação Profissional e Tecnológica: Dualidade Histórica e Perspectivas de Integração. Holos, 2(23), 4-30.

Moura, D. H. (2010). A relação entre a educação profissional e a educação básica na CONAE 2010: possibilidades e limites para a construção do novo Plano Nacional Educação. Educação e Sociedade, 31(112), 875-894.
Integrated vocational education schools 
REGE 29,2

Murillo, F. J. (2003). Una panorámica de la investigación Iberoamericana sobre eficacia escolar. Revista Electronica Iberoamericana Sobre Calidad, Eficacia y Cambio. Educación, 1(1), 14.

Murillo, F. J. (2008). Um panorama da pesquisa ibero-americana sobre a eficácia escolar. In Pesquisa em eficácia escolar: origem e trajetórias (p. 552). Belo Horizonte: UFMG.

Oliveira, A. C. P. D., \& Souza Waldhelm, A. P. (2016). Liderança do diretor, clima escolar e desempenho dos alunos: Qual a relação. Ensaio, 24(93), 824-844.

Paro, V. H. (2012). A qualidade da escola pública: a importância da gestão escolar. In A qualidade da escola pública no Brasil (p. 144). Belo Horizonte: Mazza Edições.

Passone, E. (2019). Gestão Escolar e Democracia: o que nos ensinam os estudos de Eficácia Escolar. Laplage Em Revista, 5(2), 142-156.

Ramos, M. (2008). Concepção do Ensino Médio Integrado. In Seminário promovido pela Secretaria de Educação do Estado do Pará nos dias 08 e 09 de maio de 2008 (pp. 30).

Sammons, P. (2008). As características-chave das escolas eficazes. In Pesquisa em eficácia escolar: origem e trajetórias (p. 552). Belo Horizonte: UFMG.

Sammons, P., Hillman, J., \& Mortimore, P. (1995). Key characteristics of effective schools: A review of school effectiveness research. London: Office for Standards in Education (OFSTED).

Santos Filho, J. C. D. (2015). Eficácia da Escola e Condicionantes do Desempenho Escolar dos Alunos: do Modelo Unidimensional de Análise ao Multidimensional. Roteiro, 40, 101.

Silva, I. V. D., Silva, M. T. D., \& Lima, N. D. D. S. (2020). Fatores preditivos de desempenho escolar em avaliações do SAEB: influência da gestão escolar. Research, Society and Development, 9(10), 36.

Soares, J. F. (2002). Escola Eficaz: um estudo de caso em três escolas da rede pública de ensino do Estado de Minas Gerais. Universidade Federal de Minas Gerais.

Yin, R. K. (2010). Estudo de caso: planejamento e métodos (4a edição). Porto Alegre: Bookman.

\section{Corresponding author}

Marise Regina Barbosa Uemura can be contacted at: marise.regina@hotmail.com

Associate Editor: Adriana Marotti de Mello

For instructions on how to order reprints of this article, please visit our website:

www.emeraldgrouppublishing.com/licensing/reprints.htm

Or contact us for further details: permissions@emeraldinsight.com 